\title{
Turkey-EU Relations: \\ The Limitations of Europeanisation Studies
}

Didem Buhari*

\begin{abstract}
Europeanisation studies aim at highlighting the triggering role of the EU within Turkish context. However, these studies have several deficiencies. This article intends to highlight the inherent ontological and methodological problems associated with the concept of Europeanisation in general, and for Turkey-EU relations in particular.
\end{abstract}

\section{Keywords}

Europeanisation, Turkey, the EU, Modernization, Westernization

\footnotetext{
*Didem Buhari is a PhD candidate and teaching assistant in the Department of Politics and International Relations, Royal Holloway University of London, London, UK.
} 


\section{From Geopolitics to Europeanisation}

Turkey's formal relations with the European Union (previously, European Economic Community, then European Community) date back to 1963, when it signed an Association Agreement known as 'Ankara Agreement' with the European Economic Community. However, it is plausible to claim that Turkey-EU relations were not specifically theorized until the end of the Cold War. This is due to two mutually-reinforcing assumptions. First, until the dissolution of the Soviet Union, the 'West' was perceived as a unitary bloc incorporating America and Europe as well as Japan, Australia, Canada, and New Zealand. In other words, the European was not thought as distinguished from the American in terms of ideology and political preferences. Second, given its explicitly pro-Western stance, Turkey was assumed to be an effective barrier against the spread of Communist bloc in the Middle East and Caucasus. ${ }^{1}$ In particular, the Soviet invasion of Afghanistan in 1979 and the rise of Islamist Iran increased the strategic value of Turkey in the eyes of the West. ${ }^{2}$ Therefore, the literature dealing with Turkish politics in the Cold War era tends to overemphasize Turkey's strategic location in such an extent to prevent any meaningful analysis of differences between Turkey and the West in terms of socio-economic, cultural and ideational variables.

However, in the post-Cold War era, these two assumptions have been deeply challenged, problematizing Turkey's relations with the West in general, and with Europe in particular. First of all, with the dissolution of the communist enemy, the 'West' splitted

\footnotetext{
${ }^{1}$ Doğu Ergil, "Identity Crises and Political Instability in Turkey", Journal of International Affairs, Vol. 54, No. 1 (2000), pp. 43-62; S. F. Larrabee and I. O. Lesser, Turkish Foreign Policy in an Age of Uncertainty, Pittsburgh, Rand National Security Research Division, 2002.

${ }^{2}$ Z. Öniş, "Domestic Politics, International Norms and Challenges to the State: Turkey-EU Relations in the post-Helsinki Era", Turkish Studies, Vol. 4, No.1 (2003), p. 16; Larrabee and Lesser, op.cit.
} 
Turkey-EU Relations: The Limitations of Europeanisation Studies

into two; to say differently, two 'Wests' emerged. ${ }^{3}$ The Europeans assumed full responsibility for their security and political choices, and transformed their economic Community into a political Union by the Maastricht Treaty in 1993. Accordingly, the EU set itself as an alternative political entity with distinctive choices on a wide range of policies from socio-economic preferences to normative concerns. ${ }^{4}$ This has had serious implications on Turkey-EU relations since many issues that were not on the agenda of TurkoWestern relations in the previous era, such as Turkey's approach to minority and human rights, have become potential sources of conflict in Turkey's relations with the EU. ${ }^{5}$

Furthermore, as the EU started to distinguish itself from the U.S, Turkey's close alliance with the U.S turned out to be an obstacle against its rapprochement with the Europeans. Turkey's willingness to accede to the Union and the explicit American support for Turkey's EU membership, have often been interpreted as an American strategy to introduce a 'Trojan horse' (Turkey) in order to control the political decision-making within the Union. ${ }^{6}$ In contrary to this, Turkey's denial of opening its bases to the use of American military during the second Iraqi war, has been seen by many Europeans as an act showing Turkey's affinity with the EU. Nevertheless, Turkey is claimed to be 'caught between two Wests'

3J. Habermas, The Divided West, Cambridge, Polity Press, 2006; R. Kagan, Of Paradise and Power: America and Europe in the New World Order, London, Atlantic Books, 2003; Güney N. Ateşoğlu (ed.), Contentious Issues of Security and the Future of Turkey, Burlington, Ashgate, 2007.

${ }^{4}$ I. Manners, "Normative Power Europe: A Contradiction in Terms?", Journal of Common Market Studies, Vol. 40, No. 2 (2002), pp. 235-258; S. Lucarelli, "Which Venus? A Normative Reading of the Transatlantic Divide", The Transatlantic Divide: Foreign and Security Policies in the Atlantic Alliance from Kosovo to Iraq, Osvaldo Croci and Amy Verdun (eds.), Manchester, Manchester University Press, 2006.

${ }^{5}$ William Hale, Turkish Foreign Policy, 1774-2000, London, Frank Cass, 2002.

${ }^{6}$ G. E. Fuller, "Turkey's Strategic Model: Myths and Realities", Washington Quarterly, Vol. 27, No. 3 (2004), pp. 57-59. 
and to be likely to be forced to make a decision between them in future ${ }^{7}$.

Secondly, as the Communist bloc disappeared, Turkey's role defined in the literature as a barrier against communism vanished in favour of a role of 'bridge' between Eastern and Western civilizations. This new emphasis on 'bridge' could be interpreted as the result of the 'cultural/sociological turn' in the post-Cold War academia.

The previous emphasis on Turkey as a 'barrier' refers to the theorization of Turkey's relations with the West in predominantly strategic terms. Embracing a state-centric and elite-focused approach to international relations, Cold War scholars emphasized Turkey's strategic importance for preventing the spread of communism and did not problematize Turkey's alliance with the West at societal/non-governmental level.

However, with the end of the Cold War, the strategic importance of Turkey was deeply challenged. Hence, as an attempt to respond to this challenge, the literature follows -albeit superficially- the 'cultural/sociological turn' in IR, which highlights the necessity to include societal and cultural elements into the analyses. Accordingly, the emphasis on Turkey's geographical location remained constant while Turkey's role in world politics was redefined as a 'bridge' between two major civilizations, East and West, under the influence of the 'Clash of civilizations' thesis of Samuel Huntington. ${ }^{8}$ Therefore, Turkey's strategic importance is claimed as high as Turkey would contribute to the reconciliation

${ }^{7}$ T. Mowle, "Transatlantic Relations and Turkey", Contentious Issues of Security and the Future of Turkey, Nursin Atesoglu Guney (ed.), Ashgate, Burlington 2007.

${ }^{8}$ M. Heper, "Turkey; between East and West", Institute of European Studies Papers, 2004, <http:// repositories.cdlib.org/ies/040516>.

A. Tekin, A. "Future of Turkey-EU Relations: a Civilisational Discourse", Futures, Vol. 37, No. 4 (2005), pp. 287-302. 
Turkey-EU Relations: The Limitations of Europeanisation Studies

of two oppositional cultures, whose disagreements are seen as the main source of international problems such as terrorism. ${ }^{9}$

Although the shift from 'barrier' to 'bridge' implies the welcomed introduction of certain cultural notions instead of purely strategic analyses, it does not provide a better analytical framework for understanding Turkey-EU relations. The 'bridge' approach is built on the perception that the West is a single camp (as 'Western civilization') and thus, overlooks the differences between the US and the EU. Secondly, it is problematic in the sense that it assumes Turkey as a 'bridge' rather than a part of the West/Europe. If Turkey is bridging two assumedly divergent, if not oppositional civilizations, it is thus thought as a sui generis country (or torn country in Huntington words) rather than a member of the Western civilization. Therefore, the explanatory power of the 'bridge' approach vis-à-vis Turkey's efforts and claims to be a European country is severely limited.

Finally, both 'barrier' and 'bridge' assumptions imply the same ontological rationalist stance in the sense that they both theorize Turkey-EU relations through strategic cost-benefit analyses by taking Turkish and European states' (strategic) interests fixed and predetermined. In this context, the EC/EU is thought as an institution which would be influential as long as it maximizes the self-interests of the Turkish and European state actors. Consequently, we lack the analytical tools to grasp both the opposition to Turkey's EU membership in terms of identity and culture and the ideational change in Turkey in the direction of democratization, liberalization, and the advancement of human rights.

The academic effort to fill this gap has resulted in the proliferation of Turkey's Europeanisation studies. This branch of literature deals with the change and continuities in Turkey associated with the EU conditionality. It is plausible to claim that

${ }^{9}$ R. T. Erdogan, “A Union of Civilizations”, New Perspectives Quarterly, Vol. 24, No. 3 (2007), pp. 27-29. 
Europeanisation studies have abounded following the officialization of Turkey's EU candidacy in 1999 at the Helsinki Summit. As an official candidate, Turkey has enacted significant reforms in a wide range of policy domains. ${ }^{10}$ comments that "clearly, a change of this magnitude would have been impossible in the absence of a powerful and highly institutionalised EU anchor in the directions of full membership". Studying the developments in civil-military relations and cultural rights in Turkey since 1999, Sarigil ${ }^{11}$ argues that the EU has been the main trigger in the democratization of Turkey as it has empowered pro-reform actors in Turkish political system. Thus, Europeanisation studies aim at highlighting the triggering role of the EU within Turkish context. However, these studies have several deficiencies.

\section{Limitations of the Studies on Turkey's Europeanisation}

First, these studies tends to embrace a top-down approach to the Europeanisation process, considering it as a simple and direct policy transfer from the EU to the host country, Turkey. In this context, they neglect both the discussion of the origination of the EU models and the interaction between EU and Turkey and/or between Turkey and other international institutions such as the IMF, World Bank, INGOs. Thus, there is a lack of differentiation between EU-ization (legal and formal adoption of EU acquis by state) and Europeanisation, which could be understood as a wider and deeper process that affects the cognitive schemes at societal level. ${ }^{12}$

\footnotetext{
10Z. Öniş, "Domestic Politics, International Norms and Challenges to the State: Turkey-EU Relations in the post-Helsinki Era”, Turkish Studies, Vol. 4, No. 1 (2003), pp.9-34.

11Z. Sarigil, "Endogenizing institutions", unpublished $\mathrm{PhD}$ thesis, 2007, < bttp:/ / etd.library.pitt.edu/ETD/available/ etd-04252007132125/unrestricted/Sarigil_Zeki_etd_2007.pdf>.

${ }^{12}$ A. Kaliber, "Reassessing Europeanisation as a Quest for a New Paradigm of Modernity: The Arduous Case of Turkey" Paper presented at the annual meeting of the ISA's 49th Annual Convention, Bridging Multiple Divides,
} 
Turkey-EU Relations: The Limitations of Europeanisation Studies

In addition, much of the Europeanisation studies overlook the necessity to distinguish between policy adoption and policy implementation. In this sense, they neglect the discussion of the reasons which lead to Turkey's non-implementation of the reforms it formally adopted. In particular, democratization scholars dealing with the change in civil-military relations, cultural rights of Kurdish origin people in Turkey, religious rights and minority rights face this problem. Moreover, limiting their studies to the abovementioned domains, which could be categorized as 'soft policy' areas, scholars tend to predict that Europeanisation would be limited in strategic or 'hard policy' domains such as foreign policy. ${ }^{13}$ Those studies generally rely upon realist arguments in order to assume 'Europeanisation' as opposed to 'national interests' (assumed as fixed and predetermined). This further limits the Europeanisation literature in terms of ontological openness.

Furthermore, although the EU's external relations are strongly affected by the EU's internal developments such as enlargement, much of the literature on Turkey-EU relations overlooks the internal dynamics of European integration. ${ }^{14}$ Indeed, the EU's internal dynamics have not been included into the analyses of Turkey's Europeanisation, until these became explicitly obstructive to Turkey-EU relations. Accordingly, concepts like the EU's absorption capacity ${ }^{15}$ and permanent derogations ${ }^{16}$ are generally understudied.

Hilton San Francisco, San Francisco, CA, USA, 26 March 2008 <http:// wnw.allacademic.com/meta/p254652_index.html>.

${ }^{13}$ M. Ozcan, Harmonizing Foreign Ppolicy : Turkey, the EU and the Middle East, Ashgate, Burlington, VT, 2008.

${ }^{14}$ S. E. Kahraman, "Rethinking Turkey-European Union Relations in the light of Enlargement", Turkish Studies, Vol. 1, No. 1 (2000), pp. 1-20.

${ }^{15} \mathrm{~A}$ concept introduced to the EU official texts by the European Copenhagen summit of 1993 and explicitly problematized in the context of future EU enlargement waves since the European Council of June 2006. For the discussion of this concept, see Emerson, Michael; Aydin, Senem; de ClerckSachsse, Julia; and Noutcheva, Gergana. 2006. 'Just what is this "Absorption Capacity” of the European Union?' Centre for European Policy Studies Policy Brief, No. 113, September, <http://shop.ceps.eu/downfree.php?item_id=1381>, (access date: 22 May 2009). 
Finally and most significantly, there is no scholarly consensus on the meaning of Europeanisation within the context of Turkey-EU relations. In this direction, there are three main tendencies within the extant literature on Turkey's Europeanisation.

The first tendency is to define Europeanisation in functional terms as a response/instrument vis-à-vis domestic short-term economic interests of Turkey. Hence, the change and continuities associated with Turkey's Europeanisation are explained with the cost-benefit calculus (or logic of consequentiality). In this sense, if the expected -predominantly, economic and strategic- benefits outweigh the costs -including sunk costs associated with adaptation-, domestic actors will allow for some change while their parochial interests are given. ${ }^{17}$ In this sense, this type of studies is useful to predict the domains where Europeanisation is perceived as challenge to domestic interests and resisted (e.g. cutting of statesubsidies).

However, there are several cases of Europeanisation, which cannot be explained in terms of economic-strategic benefits. For instance, Turkey has been the only country that acceded to Customs Union even before the formal acceptance of its candidacy to the EU. Economic-strategic gains out of this decision are open to discussion. ${ }^{18}$ Turkey's decision to join Customs Union is generally interpreted as a political attempt to approach the EU. ${ }^{19}$ In other words, Turkey perceives being a part of the Customs Union as a first step towards full EU membership. Accordingly, rather than short-term interests, there are long-term interests at

\footnotetext{
${ }^{16}$ The Negotiation Framework Document determining Turkey's accession negotiations with the EU states that the EU reserves the right to impose permanent derogations/limitations on three policy areas, namely agricultural subsidies, free movement of people, and structural policy (regional aid).

${ }^{17}$ F. Schimmelfennig, \& U. Sedelmeier, The Europeanization of Central and Eastern Europe, Ithaca, NY Cornell University Press, 2005.

18 Aral, 2005.

${ }^{19}$ Hale, 2000.
} 
Turkey-EU Relations: The Limitations of Europeanisation Studies

play. The second and third branches of Turkey's Europeanisation studies are mostly centred on these long-term processes.

The second tendency in Turkey's Europeanisation literature is to stress Europeanisation as part of an overall project of Modernization. Here, Modernization refers to the Ataturk's motto to reach the level of industrialized nations in terms of technological and scientific advances. In this context, Turkey has long-term interests in Europeanizing in order to become a hightechnology provider, to become industrialized and urban by reducing the gap between its regions. ${ }^{20}$ However, this type of scholarship overlooks the fact that the EU does not only provide scientific and technological know-how but also norms, principles, values and institutions such as environmental concerns, gender relations, and human rights. In this sense, this scholarship does not allow for any socialization effect. Furthermore, it is limited in terms of explaining the reasons for domestic resistance arising from cultural and identity-based concerns.

Thirdly, Europeanisation is seen as an identity-building process or 'Westernization', which would transform Turkey into a Western/European country. In this sense, this approach is distinct from the previous two in the sense that it embraces constructivist ontology. Hence, secularism, liberalism, democratic principles, minority and human rights come into play. According to this scholarship, the initiation of Westernization dates back to Tanzimat era of Ottoman empire. However, there is an apparent confusion about Turkey's own identity. The rising Islamism in Turkey is perceived as a counter-process (becoming Middle Eastern) but Turkey's Islamists are surprisingly pro-European. Besides, there is no consensus on the EU's identity. For instance, Marcussen ${ }^{21}$ explains that there are at least five interpretations of

${ }^{20}$ G. E. Fuller, "Turkey's Strategic Model: Myths and Realities," Washington Quarterly, Vol. 27, No. 3 (2004), pp. 57-59.

${ }^{21}$ M. Marcussen, T. Risse, D. Engelmann-Martin, H. J. Knopf, \& K. Roscher, "Constructing Europe? The evolution of French, British and German nation 
the EU's identity by European elite, namely (1)liberal nationalist Europe, (2) wider Europe as a community of values, (3) Europe as a democratic and socialist alternative between capitalism and communism, (4) modern Europe as part of the Western community based on liberal democracy and social market economy, and (5) Christian Europe. Finally, this type of studies is relatively underdeveloped particularly due to methodological limitations.

All of the three approaches generally consider Turkey-EU relations as separate from global cultural environment. In this context, they take for granted the origin of the models propagated as 'European'. In other words, they neglect the emergence of 'post-Western' Europe and Turkey. Furthermore, they overlook the necessity to differentiate between EU-ization (as an elitecentred formal legal process) and Europeanisation (a deeper and societal transformative cognitive process). ${ }^{22}$

This article relies upon the argument that the limitations of the extant literature on Turkey-EU relations predominantly centred upon the notion of 'Europeanisation' results from the ontological and methodological problems inherent in the Europeanisation studies. In this context, there is a need to shift from Europeanisation studies and include the global cultural dimension into the analyses of Turkey-EU relations.

\section{Europeanisation Studies in General}

Europeanisation is a relatively new theoretical concept that has become popular in contemporary EU studies. It basically

state identities", Journal of European Public Policy, Vol. 6, No.4 (1999), pp. 61433.

${ }^{22}$ A. Kaliber, "Reassessing Europeanisation as a Quest for a New Paradigm of Modernity: The Arduous Case of Turkey" Paper presented at the annual meeting of the IS A's 49th Annual Convention, Bridging Multiple Divides, Hilton San Francisco, San Francisco, CA, USA, 26 March 2008, < http:// wnw.allacademic.com/meta/p254652_index.html>. 
Turkey-EU Relations: The Limitations of Europeanisation Studies

highlights the European sources of domestic politics. ${ }^{23}$ However, it is often criticized for producing more questions than answers.

In particular, its definition remains ambiguous as scholars use Europeanisation to indicate at least five different processes associated with the European integration: territorial expansion (widening), institutional expansion (deepening), institutional adaptation of national or sub-national polities' to the EU rules and norms, diffusion of the EU rules and norms to non-EU areas of the globe, and finally, the political unification of the EU as a global actor. $^{24}$

Hence, Europeanisation is used to explain policy change, administrative innovation, cultural change, and new identity formation, which renders the term ambiguous, if not meaningless. ${ }^{25}$ Given this ambiguity, Europeanisation scholars need to avoid 'concept stretching' by providing a clear differentiation of the Europeanisation from other concepts such as integration, convergence and harmonization. ${ }^{26}$

Although it can be used to indicate an outcome (e.g. national foreign policy is Europeanised), it is useful to define it as a process in order to differentiate a process from its results such as convergence and harmonization. ${ }^{27}$

${ }^{23} \mathrm{M}$ Vink,., "What is Europeanization? And Other Questions on a New Research Agenda”, European Political Science, Vol. 3, No. 1 (2003), pp. 63-74.

${ }^{24}$ J. Olsen, "The Many Faces of Europeanization", Journal of Common Market Studies, Vol. 40, No. 5 (2002), pp. 921-52.

${ }^{25}$ C. M. Radaelli, "Whither Europeanization? Concept stretching and substantive change", 2000, <http:/ / eiop.or.at/ eiop/texte/2000-008.htm>.

K. E. Howell, "Developing Conceptualisations of Europeanization: Synthesising Methodological Approaches", Queens University On-Line Journal, Paper No. 3 (2004), 2004, pp. 1-15.

${ }^{26}$ Idem.

M. Vink, "What is Europeanization? And Other Questions on a New Research Agenda", European Political Science, Vol. 3, No. 1 (2003), pp. 63-74.

${ }^{27}$ C. M. Radaelli, "Whither Europeanization? Concept stretching and substantive change", 2000, <http:/ / eiop.or.at/ eiop/texte/2000-008.htm>. 


\section{Europeanisation as an Incremental Process Leading to Peaceful Change}

The review of Europeanisation literature shows that first, Europeanisation process is mostly viewed as incremental rather than radical or abrupt. ${ }^{28}$ It is diffuse over time and space. Consequently, longitudinal studies would be necessary. Second, it implies peaceful change at domestic level, excluding cases of coercion. In this sense, the research question is how Europeanisation leads to peaceful transformation at domestic level.

Rather than coercion, the EU resorts to conditionality, including economic and strategic incentives. ${ }^{29}$ Furthermore, the EU influences states by altering existing domestic opportunity structures and the power distribution among domestic actors; ${ }^{30}$ and finally, the European discourse has a potential transformative and persuasive power on domestic sphere through its cognitive influence on identities and ideas. ${ }^{31}$

In this context, Europeanisation studies have exponentially increased during the accession process of the Central and Eastern European Countries to the EU. Those countries' transition to

${ }^{28} \mathrm{R}$. Ladrech, "Europeanization of Domestic Politics and Institutions: The Case of France", Journal of Common Market Studies, Vol. 32 (1994), pp. 69-88.

${ }^{29} \mathrm{~F}$.Schimmelfennig, and U. Sedelmeier, The Europeanization of Central and Eastern Europe, Ithaca/NY, Cornell University Press, , 2005.

${ }^{30}$ T Börzel,. \& T. Risse, , "Conceptualizing the Domestic Impact of Europe", The Politics of Europeanization, eds. K. Featherstone and C. Radaelli, Oxford ,Oxford University Press, , 2003.

${ }^{31}$ C. M Radaelli,.. "Europeanisation: Solution or Problem”, EIoP online working paper series, 8/16, 2004; J. Checkel, "Norms, Institutions, and National Identity in Contemporary Europe", International Studies Quarterly, Vol. 43, No. 1 (1999), pp. 84-114; T. Risse, "A European identity? Europeanization and the evolution of nation-state identities", in Transforming Europe: Europeanization and Domestic Change, eds. M. G. Cowles, J. Caporaso and T. Risse, Cornell University Press, Ithaca London, 2001. 
Turkey-EU Relations: The Limitations of Europeanisation Studies

liberal economy and democracy has been presented as successful cases of Europeanisation. ${ }^{32}$ However, conceptualizing Europeanisation as a 'top-down' and unidirectional process has been under severe criticisms for its overlooking of the states' role in the context of Europeanisation. ${ }^{33}$ explains that from a top-down perspective, Europeanisation misleadingly refers to a unidirectional process whereby states are assumed to simply 'download' the EU policies.

A significant number of Europeanisation scholars seek to explain the impact of European integration on domestic sphere. ${ }^{34}$ However, it is often overlooked that Europeanisation and European integration are in a continuous interaction. ${ }^{35}$

There is an increasing emphasis on the complex nature of Europeanization, which involves an iterative and interactive relationship between member-states and the EU. ${ }^{36}$ In this sense, Europeanisation is not unidirectional since ideas and pressures flow in both directions' between the EU and member states.

\footnotetext{
${ }^{32}$ Schimmelfennig and Sedelmeier, ibid.

${ }^{33}$ Kerry Howell, "Developing Conceptualizations of Europeanization and European Integration: Mixing Methodologies", ESRC Seminar 1/UACES Study Group 2, 29 November 2002, p. 20.

${ }^{34}$ M. W. Bauer, C. Knill and D. Pitschel, "Differential Europeanization in Eastern Europe: The Impact of Diverse EU Regulatory Governance Patterns", Journal of European Integration, Vol. 29, No. 4 (2007), pp. 405-423; Schimmelfennig and Sedelmeier, ibid.

M. G.,Cowles, J. Caporaso, and T. Risse, (eds), Transforming Europe: Europeanization and Domestic Change, London, Cornell University Press, 2001; C. Knill, The Europeanization of National Administrations: Patterns of Institutional Change and Persistence, Cambridge ,Cambridge University Press, 2001; Goetz, K.\&Hix S. (eds.), Europeanised Politics? European Integration and National Political Systems, London, Frank Cass Publishers, , 2001.

Y. Meny, P. Muller and J. Quermonne, Adjusting to Europe: The Impact of the European Union on National Institutions and Policies, London, Routledge, 1996.

${ }^{35}$ Kerry Howell, "Developing Conceptualizations of Europeanization and European Integration: Mixing Methodologies", ESRC Seminar 1/UACES Study Group 2, 29 November 2002, p. 9.

${ }^{36}$ Ibid.
} 
Therefore, both top-down and bottom-up processes need to be included in the Europeanisation analyses because domestic and EU-levels of policy making are interdependent through 'vertical and horizontal networks and institutional linkages.

In this framework, Radaelli ${ }^{37}$ provides a comprehensive definition of Europeanisation as 'processes of (a) construction, (b) diffusion, (c) institutionalisation of formal and informal rules, procedures, policy paradigms, styles, 'ways of doing things', and shared beliefs and norms which are first defined and consolidated in the making of EU decisions and then incorporated in the logic of domestic discourse, identities, political structures and public policies.'

\section{Understanding Differentiated Responses at Domestic Level}

A related research question involves the reasons for domestic opposition to Europeanisation as well as differentiated responses and patterns of adaptation at domestic level. In other words, if the ultimate aim of Europeanisation is the convergence of national policies with the EU, it is necessary to ask why it fails in particular instances. Hence, the extant scholarship discovers a 'missing link' between EU stimuli and domestic outcomes. ${ }^{38}$

In this context, there are two main tendencies among researchers: first, the nature and strength of the EU-level stimuli (direct/indirect, hard/soft) are highlighted as the main cause of the varying domestic responses. Accordingly, Featherstone and Papadimitriou $^{39}$ suggest that stimulus for domestic change is stronger in cases where the EU acts on the basis of 'hard law', i.e.

${ }^{37}$ C. M. Radaelli, "Whither Europeanization? Concept stretching and substantive change", 2000, <http://eiop.or.at/ eiop/texte/2000-008.htm>.

${ }^{38} \mathrm{~K}$. Featherstone and D. Papadimitriou, The limits of Europeanization: reform capacity and policy conflict in Greece, Basingstoke/UK, Palgrave Macmillan, 2008, p. 2.

${ }^{39}$ Ibid., p. 4. 
Turkey-EU Relations: The Limitations of Europeanisation Studies

Treaty competences and legislative directives, in comparison to the cases where the EU rules are non-enforceable (soft law- eg. Open Method of Coordination). Furthermore, Knill and Lehmkuhl ${ }^{40}$ suggest that the type of EU policy transferred is also crucial: positive integration directly addresses the institutional system at the national level, negative integration redistributes power and alters domestic actor constellations, and "framing" integration transforms beliefs and expectations of domestic actors.

Second tendency is to stress the variation in the domestic resources, capabilities, historical past and institutional structures among states and to claim that the "goodness of fit", i.e. the congruence between national and European policies/institutions, determines the degree of EU adaptational pressures and state compliance..$^{41}$ In this context, there are at least three variables that are associated with the domestic structure: national identityhistory, political ideology, socio-economic costs related to Europeanisation.

First, national identity is defined as shared ideas with a sense of community that is assumed as distinct from other social groups. ${ }^{42}$ Radical and frequent changes in identity are unlikely. Particularly the Second World War experience has been considered as influential on the European states' attitude towards European

${ }^{40}$ C. Knill and D. Lehmkuhl, "How Europe Matters: Different Mechanisms of Europeanization", European Integration online Papers (EIoP), Vol. 3, No. 7 (1999).

${ }^{41}$ E.Mastenbroek, M:Kaeding, "Europeanization Beyond the Goodness of Fit: Domestic Politics in the Forefront", Comparative European Politics, Vol. 4, No. 4, (2006), pp. 331-354; A. Héritier, D. Kerwer, C. Knill, D. Lehmkuhl and D. Teutsch, Differential Europe: The European Union Impact on National Policy-Making, Lanham, MD, 2001.

${ }^{42}$ M. Marcussen, T. Risse, D. Engelmann-Martin, H. J. Knopf and K. Roscher, "Constructing Europe? The evolution of French, British and German nation state identities", Journal of European Public Policy, Vol. 6, No. 4 (1999), pp. 61433. 
integration. ${ }^{43}$ It is used as an explanatory factor that affects the definition of "self" and the "other". ${ }^{44}$ Accordingly, national identity and history could limit or encourage Europeanisation at the domestic level.

Second, the ideological beliefs that political parties promote are influential on state preferences towards the EU effects in the sense that they constrain the possibility of policy positions. In particular, the left-right dyad is studied in order to explain variations in party positions towards the EU. ${ }^{45}$ Aspinwall ${ }^{46}$ suggests that the centrist ideology supports the EU mostly with pragmatic incentives for achieving prosperity and stability whereas ideologies of right and left are more inclined to oppose the EU in order to preserve the domestic autonomy. The right stresses on the need to maintain national identity and security while the left to protect welfare state mechanism via controlling the market forces. ${ }^{47}$

Third, changing the status quo undermines the interests of particular actors. Those interests might be social, economic and political. For instance, the standardization of products might threaten private interests of particular actors such as the French farmers opting for the continuation of state subsidies. Thus, the European Union requires the end of subsidizing as it is against the EU competition rules. Another political interest at stake might arise out of the EU conditionality on increasing civilian control on the military. Finally, governments claim that their strategic interests

\footnotetext{
${ }^{43}$ M.Aspinwall, "Government preferences on European integration: an empirical test of five theories", British Journal of Political Science, Vol. 37, No. 1 (2007), pp. 89-114.

${ }^{44}$ Ibid., p. 93.

${ }^{45}$ M.Gabel and J.Huber, "Putting Parties in their Place: Inferring Party LeftRight Ideological Positions from Party Manifestos Data", American Journal of Political Science, Vol. 44 (2000), pp. 94-103.

${ }^{46} \mathrm{M}$. Aspinwall, Rethinking Britain and Europe: Plurality Elections, Party Management, and British Policy on European Integration, Manchester, Manchester University Press, 2004.

${ }^{47}$ Ibid.
} 
are threatened by the EU in sectors related particularly to natural resources and energy.

Apart from interest-based costs, there are also sunk costs associated with the institutions. If the policy area where the EU demands change is a well-established domain, changing the established patterns of behaviour and distribution of authority might prove to be costly. The essence of the cost-oriented resistance is related to the prioritisation of the EU membership. If the expected benefits from EU membership outweigh the aforementioned costs, domestic change is more likely.

Moreover, states' characteristics related to all of the three factors are often embedded in traditional 'ways of doing things', standard operating procedures, routines and institutions. Olsen ${ }^{48}$ states that: An institutional perspective suggests that diffusion will be affected by the interaction between outside impulses and internal institutional traditions and historical experiences. Diffusion processes are unlikely to produce perfect cloning of the prescriptions offered. What is diffused is likely to be transformed during the process of diffusion.

This implies that Europeanisation involves a process through which EU stimuli are received, translated and adopted or rejected. In this framework, Europeanisation scholars tend to embrace institutionalist approaches that provide analytical tools to identify institutional mechanisms underlying domestic change and continuities. In other words, Neo- institutionalism is used in order to grasp the institutional facilitators or veto players in the context of Europeanisation.

${ }^{48} \mathrm{~J}$. Olsen, "The Many Faces of Europeanization", Journal of Common Market Studies, Vol. 40, No. 5 (2002), pp. 921-52. 


\section{Neo-Institutionalism and EU Studies}

Neo-institutionalist approaches provide a promising alternative to the mainstream theories on the EU for several reasons. First, they bring into the analyses the interaction between domestic and institutional spheres and thus, break the hypothetical boundaries between comparative politics and International Relations. ${ }^{49}$ Therefore, the mediating effects of the domestic institutions within the European integration context, is no more neglected. ${ }^{50} \mathrm{Neo}$-institutionalism is thus promising for its emphasis on intervening variables and processes rather than solely the "start" and "finish" of a phenomenon. ${ }^{51}$ Secondly, neoinstitutionalism is more suitable for its theoretical compatibility with a great number of political cases unlike neo-functionalist and intergovernmental approaches that are limited to the European integration. ${ }^{52}$ Thirdly, neo-institutionalist approaches provide testable hypotheses that lack in the traditional EU literature..$^{53}$

Neo-institutionalism is useful to study processes of Europeanisation because it provides explanatory frameworks for the differential patterns of national behaviour vis-à-vis the EU pressures $^{54}$. It thus suggests:

Differing national senses of appropriate institutional forms, coupled with path-dependent logics of adjustment, account for the persistence of national politico-administrative models in the face

${ }^{49}$ M. Pollack, "The New Institutionalisms and European Integration", in European Integration Theory, eds. A. Wiener and T. Diez, Oxford, Oxford University Press, 2004.

${ }^{50}$ Ibid.

${ }^{51} \mathrm{~A}$. George and A.Bennett, Case studies and theory development in the social sciences, Cambridge, MIT Press, 2005, p. 7.

${ }^{52}$ Ibid.

${ }^{53}$ Ibid.

${ }^{54} \mathrm{R}$ Harmsen and T. M. Wilson, Europeanization: institution, identities and citizenship, Rodopi, 2000. 
Turkey-EU Relations: The Limitations of Europeanisation Studies

of what many have presumed to be growing pressures for institutional convergence. ${ }^{55}$

In his path-breaking article, Pierson explains that there are three reasons for the emergence of the gaps in member states' control over the EU. First, the EU institutions are capable of using their own resources in order to develop autonomous interests and play off member states against each other. ${ }^{56}$ Schmidt provides the example that the European Commission uses agenda-setting power and also, it uses strategically the discretionary power of the European Court of Justice to enforce the EU policies on member states. ${ }^{57}$ Second, Pierson ${ }^{58}$ argues that in general, the institutional design makes substantial and radical changes difficult. This is due to the designers' will to prevent any future control of the institutions by their opponents. ${ }^{59}$ For instance, in the European Union it is difficult to amend founding treaty provisions as it requires that all member states should agree with it following the unanimity rule and should ratify it in their national Parliaments. These procedural difficulties hinder substantial and quick institutional amendments by national governments. Third, Pierson $^{60}$ emphasizes the path-dependence process during which agents face the cost of reversing the institutions. Hence, previous institutional decisions lock the members in as the sunk costs related to societal adaptation prevent their exit. Hall and Taylor ${ }^{61}$ add that apart from the material costs of exit, there are also particular identities related to institutions that constrain agents. Hence, it is also costly to reverse previous institutional decisions in

\footnotetext{
${ }^{55}$ Ibid.

${ }^{56} \mathrm{P}$. Pierson, "The Path to European Integration A Historical Institutionalist Analysis", Comparative Political Studies, Vol. 29, No. 2 (1996), pp. 123-163.

${ }^{58}$ P. Pierson, "The Path to European Integration A Historical Institutionalist Analysis”, Comparative Political Studies, Vol. 29, No. 2 (1996), p. 142.

${ }^{59}$ Ibid., p. 143.

${ }^{60}$ Ibid., p. 144.

${ }^{61} \mathrm{P}$. Hall and R Taylor "Political Science and the Three New Institutionalisms", Political Studies, Vol. 44 (1996), pp. 936-957.
} 
ideational terms. In brief, the concept of path-dependence explains why those institutions whose efficiency and necessity are contested persist.

Furthermore, Pierson's historical institutionalist analysis implies a focus on prior and later events and processes rather than a "snapshot view" of the subject of interest. ${ }^{62}$ In other words, not only the correlations among variables but also the time sequence should be evaluated. In this sense, the underlying processes inhibiting or facilitating causal forces over time and threshold effects should be studied. ${ }^{63}$ This type of study generally requires rich longitudinal data sets. ${ }^{64}$ In methodological terms, it poses the problem of "many variables, few cases" together with an additional temporal dimension requiring longitudinal data.. ${ }^{65}$

Finally, mainly for these methodological reasons, Historical institutionalism limited itself to explain contingent cases by induction and thus, has been slower to advance comprehensive and empirically testable theories. ${ }^{66}$ Lack of focus in the domestic agency makes Historical Institutionalism subject to criticisms of determinism. Institutional persistence over time is self-reinforcing. However, Europeanisation involves both change and continuities. In this context, introducing domestic agency into the analysis is necessary. ${ }^{67}$ Alternatively, Europeanisation studies focus on

${ }^{62}$ P. Pierson, "The Study of Policy Development," Journal of Policy History, Vol. 17, No. 1 (2005), pp. 37-56.

${ }^{63}$ Ibid.

${ }^{64} \mathrm{P}$. Pierson, Politics in time: history, institutions, and social analysis, Princeton University Press, 2004, p. 173.

${ }^{65}$ Ibid.

${ }^{66} \mathrm{P}$. Hall and R. Taylor, "Political Science and the Three New Institutionalisms", Political Studies, Vol. 44 (1996), pp. 936-957.

M. Pollack, "The New Institutionalisms and European Integration", European Integration Theory, A. Wiener and T. Diez (eds.), Oxford, Oxford University Press, 2004.

${ }^{67}$ J. Checkel, "Norms, Institutions, and National Identity in Contemporary Europe”, International Studies Quarterly, Vol. 43, No. 1 (1999), pp. 84-114. 
Turkey-EU Relations: The Limitations of Europeanisation Studies

Rational Choice and Sociological institutionalisms in order to explain the differential impact of the EU on domestic politics.

In the context of EU-state relations, both Rational choice and Sociological institutionalists present the EU as an external systemic force having the capacity to alter domestic structures in terms of policy, polity and politics. Rational choice and Sociological institutionalisms represent two alternative logics of behaviour at the domestic level: 'logic of consequentiality' and 'logic of appropriateness'. ${ }^{68}$ According to Sociological institutionalists, Europeanisation processes involve the mediation of the integration process by the national institutional structures through logic of appropriateness. ${ }^{69}$

However, these approaches disagree on the extent of the EU effect; by focusing on formal institutions (formal EU rules and regulations) and conditionality, the rationalist choice institutionalists claim that the EU's transformatory power is rather limited ${ }^{70}$, while the sociological approach includes ideational, normative and cognitive factors to the definition of EU institutions and see the EU as a model or promoter of socialization and norm diffusion. ${ }^{71}$ In this context, Vink ${ }^{72}$ proposes two types

${ }^{68} \mathrm{~J}$. G. March, and J. P. Olsen, "The institutional dynamics of international political orders", International Organization, Vol. 52, No. 4 (1998), pp. 943-969.

${ }^{69}$ R. Harmsen and T. M. Wilson, Europeanization: institution, identities and citizenship, Rodopi, 2000.

${ }^{70} \mathrm{~F}$. Schimmelfennig, and U. Sedelmeier, The Europeanization of Central and Eastern Europe, Ithaca, NY, Cornell University Press, 2005.

${ }^{71} \mathrm{P}$. Hall and R. Taylor "Political Science and the Three New Institutionalisms", Political Studies, Vol. 44 (1996), pp. 936-957; J. Checkel, "Norms, Institutions, and National Identity in Contemporary Europe", International Studies Quarterly, Vol. 43, No. 1, pp. 84-114; J. Jupille, J. Caporaso and J.Checkel, 'Integrating Institutions: Rationalism, Constructivism, and the Study of the European Union', Comparative Political Studies, Vol. 36, No. 1/2 (2003), pp. 7-41; T. Risse, "A European identity? Europeanization and the evolution of nation-state identities", Transforming Europe: Europeanization and Domestic Change, ed. M. G., 2001.

${ }^{72}$ M. Vink, "What is Europeanization? And Other Questions on a New Research Agenda”, European Political Science, Vol. 3, No.1 (2003), pp. 63-74. 
of Europeanisation, namely Thin and Thick Europeanisation. Thin Europeanisation follows the Rational Choice institutionalism and demonstrates a limited and behavioural change under the EU pressures while Thick Europeanisation reinforces Sociological institutionalism that allows for substantial EU effect and profound changes at domestic level.

In addition to the extent of the EU effect on states, Europeanisation scholars disagree also on the relationship between 'calculus' and 'cultural' approaches of Neo-institutionalism. While some view the two approaches as complementary in explaining different phases of domestic change ${ }^{73}$, some think they are mutually exclusive. ${ }^{74}$

Europeanisation research has enriched the EU studies by investigating under-researched issues such as the differentiated implementation of EU policies at domestic level, the change in the organizational logic of domestic politics due to the EU pressures, and in national political issues such as political parties, party systems, local government, refugee policies and citizenship. ${ }^{75}$ Furthermore, there is a welcome tendency to include non-member states as case studies of Europeanisation. For instance, EU candidate states are deeply embedded in the EU network through accession negotiations and thus, prone to be influenced by the EU conditionality. ${ }^{76}$ Additionally, several Europeanisation works focus on the transformative power of the EU in terms of democracy, human rights, liberal market economy in the non-EU areas of the world. However, Europeanisation studies have also attracted strong criticisms.

\footnotetext{
${ }^{73}$ M. Finnemore and K. Sikkink, "International Norm Dynamics and Political Change”, International Organization, Vol. 52, No. 4, pp. 887-917.

${ }^{74} \mathrm{M}$. Vink, "What is Europeanization? And Other Questions on a New Research Agenda", European Political Science, Vol. 3, No.1 (2003), pp. 63-74.

${ }^{75} \mathrm{Idem}$.

${ }^{76}$ M. W. Bauer, C. Knill \& D. Pitschel, "Differential Europeanization in Eastern Europe: The Impact of Diverse EU Regulatory Governance Patterns", Journal of European Integration, Vol. 29, No. 4 (2007), p.416.
} 


\section{Methodological Issues}

Europeanisation scholars have often resorted to positivist methodology, specifying independent variable as the 'EU effect' and dependent variable as 'domestic change' and claiming a causal relationship mostly through case-studies. ${ }^{77}$ However, their case selection is criticized for being biased in favour of EU-level explanations since they investigate the cases where the independent variable, the EU influence, is invariably present. ${ }^{78}$ Accordingly, separating the effect of the EU from the impacts of the domestic and global forces becomes difficult, if not impossible. In response to this criticism, Europeanisation scholars suggest to use process-tracing, which takes into consideration alternative explanatory factors and to distinguish the EU effect from other factors through a careful analysis of timing. ${ }^{79}$ Although these studies are accepted to enrich our knowledge of how the EU matters' in domestic politics, they fail to account for the extent of the EU effect. ${ }^{80}$ In this sense, process tracing is useful to uncover the mediating factors such as domestic veto players and political culture but cannot dissipate the risk of 'analytical oversight' by failing to understand the effect of the wider global forces that might overshadow the EU effect ${ }^{81}$. Investigating the change in domestic economic policies in 21 countries found that seven of them could be explained by the EU effect while another seven of

\footnotetext{
${ }^{77}$ For more information see: T. Jeffrey Checkel (ed.), International Institutions and Socialization in Europe, 2001.

${ }^{78} \mathrm{M}$. Haverland, "Does the EU cause domestic developments? improving case selection in Europeanisation research", West European Politics, Vol. 29, No. 1 (2006), pp. 134-146.

${ }^{79}$ T. Jeffrey Checkel (ed.), International Institutions and Socialization in Europe, 2001.

${ }^{80} \mathrm{M}$. Haverland, "Does the EU cause domestic developments? Improving case selection in Europeanisation research", West European Politics, Vol. 29, No. 1 (2006), pp. 134-146.

${ }^{81} \mathrm{M}$. Haverland, "Does the EU cause domestic developments? improving case selection in Europeanisation research", West European Politics, Vol. 29, No. 1 (2006), p. 51.
} 
them by globalization, and the rest by the mixture of different sources of adaptation pressures.

A methodological remedy is to ensure that the selected cases (countries, sectors, institutions etc.) demonstrate variation in the EU variable. However, this poses the question of choosing between 'most similar cases' and 'most different cases'. On the one hand, the former necessitates finding cases where the EU effect varies but other variables are similar. This raises two concerns. First, the researcher faces the 'small-N problem', which explains the difficulty to find suitable cases. Second, it is difficult to ensure that the EU effect varies among the cases. Even in case of the absence of a visible effect, the EU might have been influential in the control case (where the EU effect is hypothetically absent) through diffusion, learning and mimicking, which are difficult to demonstrate in empirical terms.

For instance, comparing an EU member state with a nonEU member state through 'most similar systems' design could lead us to compare the U.K. (EU member) with Norway (Nonmember) for the similarity in their geographical location, history, socio-economic structure. However, this would not prevent the claims that the EU had a significant impact in Norway although the latter is not an EU member. ${ }^{82}$

On the other hand, 'most different systems' design requires the selection of control cases that are dissimilar to our Europeanisation cases. However, this would limit our understanding of the EU effect as the variation in outcomes between Europeanisation cases and the control cases might have been caused by other factors instead of the EU variable. Haverland gives the example of a Europeanisation study that seeks to explain the effect of the EU directive on telecommunications for the protection of privacy and to this aim, compare an EU member

${ }^{82} \mathrm{M}$. Haverland, "Does the EU cause domestic developments? Improving case selection in Europeanisation research", West European Politics, Vol. 29, No. 1 (2006), pp. 134-146. 
Turkey-EU Relations: The Limitations of Europeanisation Studies

state with a Latin American country (since these are very dissimilar regarding several issues such as their socio-economic development and political system.) Yet, demonstrating the variation between those countries in terms of privacy protection in telecommunications is insufficient to claim that this variation is caused by the EU directive. Rather, the variation might be the result of differences in the strength of democratic values. ${ }^{83}$

Haverland ${ }^{84}$ suggests that cross-section comparison within EU member states could be another remedy to increase the variation in the independent variable. In other words, the Europeanisation researcher could compare sectors that are under direct EU pressure with those where the EU influence is absent in order to trace the EU effect by controlling all national factors. However, one faces the same dilemma between the designs of 'most similar' and most different' systems. If the sectors that are similar are chosen, it is necessary to consider the blurring of the sectoral boundaries and the potential EU's 'horizontal effects' between sectors through adaptation and learning. Otherwise, if the design follows the 'most different systems', the variation in outcomes could be caused by sector-specific factors rather than the EU effect.

\section{Need to Differentiate Europeanisation from Integration, Harmonization and Convergence}

EU studies have long been centred around the concept of integration, defined as the establishment of new policies, institutions and norms at the EU level. ${ }^{85}$ Integration studies are generally framed by two theoretical approaches, namely Intergovernmentalism and neo-functionalism, both stressing member states' delegation of partial sovereignty to the European

\footnotetext{
${ }^{83} \mathrm{Idem}$.

${ }^{84}$ Idem.

${ }^{85} \mathrm{C}$ Rumford, and P. Murray, "Globalization and the limitations of European integration studies: interdisciplinary considerations", Journal of Contemporary European Studies, Vol. 11, No. 1 (2003), pp. 85-93.
} 
institutions such as the Commission and the Court of Justice. According to Caporaso and Stone Sweet ${ }^{86}$, both approaches are insufficient to understand the dynamic process of European integration. Intergovernmentalism understates the contextual influence of the European rule structures on "grand bargains", i.e. governmental decision-making whereas Neo-functionalism remains within the functional efficiency realm and does not offer an alternative rigorous theory of positive integration. ${ }^{87}$ Furthermore, an overemphasis on the integration would fail to grasp domestic opposition against the spread of the EU norms, institutions and rules as well as EU membership at national and sub-national levels. ${ }^{88}$ European integration could be seen as the cause for domestic change while Europeanisation either as the transformatory process or as the outcome. ${ }^{89}$

There is a tendency to define European integration as the development of supranational institutions at the EU level whereas Europeanization as the 'feedback process of European integration at domestic level'. Accordingly, 'Europeanisation proceeds independently of European integration.' If studies define Europeanisation as unification and use it interchangeably with European integration, the term would fail to add explanatory power to the EU studies and would become unnecessary. ${ }^{90}$

${ }^{86} \mathrm{~J}$. Caporaso and A. Stone Sweet, "Institutional Logics of Integration", in The Institutionalization of Europe, eds. A. Stone Sweet, W. Sandholtz and N. Fligstein, Oxford, Oxford University Press, 2001.

${ }^{87}$ Idem.

${ }^{88} \mathrm{C}$ Rumford, \& P. Murray, "Globalization and the limitations of European integration studies: interdisciplinary considerations", Journal of Contemporary European Studies, vol. 11, no. 1, 2003, pp. 85-93.

${ }^{89}$ Kerry Howell, "Developing Conceptualizations of Europeanization and European Integration: Mixing Methodologies", ESRC Seminar 1 / UACES Study Group 2, 29 November 2002, p.20.(Hix and Goetz 2000)

${ }^{90}$ S. Zimmer, "On Indo-Europeanization", Journal of Indo-European Studies, Vol. 18, No. 1-2 (1990), pp. 141-156. 
In fact, the idea of integration involves ontological problems that could limit EU studies ${ }^{91}$ Integration might refer to a structure of interdependence or interaction among elementary parts as well as a structure of meaning and consistency. ${ }^{92}$ Integration studies assume these dimensions are strongly correlated in spite of the contradictory empirical evidence. Furthermore, the concept of integration is closely linked to the idea of cohesion and fails to differentiate between functional economic integration and democratic integration. Therefore, it is plausible to argue that Europeanisation allows for empirical analyses of the differentiated patterns of behavior under the conditions of mutual interdependence, increased contacts and shared projects. ${ }^{93}$

It is increasingly accepted that Europeanisation does not necessarily lead to convergence. Convergence among EU regimes could happen for non-EU reasons such as change in domestic government or global pressures. In this sense, it should not be considered as synonymous for Europeanisation. Similarly, it cannot be defined as harmonization since its asymmetrical effects on 'policy sectors, geographic regions, the penetration of domestic settings in their depth and breadth and timing' are increasingly highlighted. ${ }^{94}$ Therefore, although harmonization is the ultimate objective of the European integration, it is different from Europeanisation, which involves differential impact of EU rules on domestic policies and continued national diversity. ${ }^{95}$

Moreover, Bomberg and Peterson ${ }^{96}$ question the link between policy transfer and Europeanization. Policy transfer is

${ }^{91}$ Ibid., pp. 134-135.

${ }^{92}$ Idem.

${ }^{93}$ Idem.

${ }^{94} \mathrm{~K}$. Featherstone and D. Papadimitriou, The limits of Europeanization: reform capacity and policy conflict in Greece, Basingstoke, UK, Palgrave Macmillan, 2008.

${ }^{95}$ M. Vink, "What is Europeanization? And Other Questions on a New Research Agenda", European Political Science, Vol. 3, No. 1 (2003), pp. 63-74.

${ }^{96}$ Kerry Howell, "Developing Conceptualizations of Europeanization and European Integration: Mixing Methodologies", ESRC Seminar 1 / UACES Study Group 2, 29 November 2002. 
mainly defined as a "process in which knowledge about policies, administrative arrangements, institutions and ideas in one political setting (past or present) is used in the development of policies, administrative arrangements, institutions and ideas in another political setting". ${ }^{97}$ This process might include varying degrees of voluntary (lesson-drawing) and coercive transfers (direct imposition).

Similarly, Howell ${ }^{8}$ suggests that Europeanisation involves two processes of policy transfer: first, a horizontal process where the EU does not involve directly and member states adapt themselves to EU standards through learning or mimicking, and secondly explicit Europeanisation where the EU requirements lead to a vertical policy transfer. The horizontal policy transfer includes shared beliefs, discourses and cognitive schemes that are incorporated in the domestic identities and cultural framework. Howell thinks that it is necessary to distinguish these processes and accepts the vertical policy transfer as part of Europeanisation while considering the horizontal policy transfer just as the content of Europeanisation.

\section{On the EU Agency}

There are several questions that Europeanisation literature has not been able to answer. For instance, does the Europeanisation intends to build an EU super-state centred in Brussels? Could the transfer of the EU models be equated to imperialism? Dobson ${ }^{99}$ thus asks how to justify further Europeanisation in the eyes of the national societies. It is generally accepted that the EU institutions are neither the antithesis nor an alternative to national governments. This is mainly explained by the

\footnotetext{
${ }^{97}$ D. P. Dolowitz and D.Marsh, "Learning from Abroad: The Role of Policy Transfer in Contemporary Policy-Making", Governance, Vol. 13, No. 1 (2000), pp. 5-24.

${ }^{98}$ Howell, "Developing Conceptualizations...".

${ }^{99}$ L. Dobson, "Normative Theory and Europe", International Affairs, Vol. 82, No. 3 (2006), p. 511-523.
} 
Turkey-EU Relations: The Limitations of Europeanisation Studies

'Democratic deficit' argument based on the absence of a genuine 'European' demos (For the discussion of democratic deficit ${ }^{100}$.

Secondly, the EU's relationship with Globalisation is understudied. Is the EU an agent of globalisation or a reaction to it? Does it shape globalisation or is it shaped by global forces? There is a need to forego economistic aproaches towards globalisation and consider the social forces and cultural aspects of the globalisation.

Finally, it is also probable that domestic actors could proactively use Europeanisation as an ideological force for modernization and thus, attempt at transposing the EU impacts into a wider reform paradigm. ${ }^{101}$ For instance, although the EU requirements on single market does not require the change in the ownership structure of the state enterprise, Greek domestic actors used the EU agenda to further privatization in national airlines. ${ }^{102}$ Therefore, the analytical differentiation between Europeanisation and Modernisation become difficult.

\section{Concluding Remarks}

In this article, it is argued that studying Turkey's relations with the European Union requires a more sophisticated approach than that is provided by the Europeanisation scholarship. It is plausible to claim that Europeanisation studies have abounded following the officialization of Turkey's EU candidacy in 1999 at the Helsinki Summit. As an official candidate, Turkey has enacted significant reforms in a wide range of policy domains. Thus, Europeanisation studies aim at highlighting the triggering role of

${ }^{100} \mathrm{G}$. Majone, Dilemmas of European Integration, Oxford, Oxford University Press, 2005.

${ }^{101} \mathrm{~K}$. Featherstone and D. Papadimitriou, The Limits of Europeanization; reform capacity and policy conflict in Greece, Basingstoke, Palgrave-Macmillan, 2008, p. 28.

${ }^{102}$ Ibid., p. 30. 
the EU within Turkish context. However, these studies have several deficiencies.

First, these studies tends to embrace a top-down approach to the Europeanisation process, considering it as a simple and direct policy transfer from the EU to the host country. In addition, much of the Europeanisation studies overlook the necessity to distinguish between policy adoption and policy implementation. Furthermore, these studies generally rely upon realist arguments in order to assume 'Europeanisation' as opposed to 'national interests', which limits the Europeanisation literature in terms of ontological openness. In addition, the EU's internal dynamics have not been included into the analyses of Turkey's Europeanisation, until these became explicitly obstructive to Turkey-EU relations.

Finally and most significantly, there is no scholarly consensus on the meaning of Europeanisation within the context of Turkey-EU relations. In this direction, there are three main tendencies within the extant literature on Turkey's Europeanisation: (1) functional response to European conditionality, (2) as part of an overall project of modernization, (3) as an identity-building process, known as Westernization. All of the three approaches generally consider Turkey-EU relations as separate from global cultural environment. In this context, they take for granted the origin of the models propagated as 'European'. In other words, they neglect the emergence of 'postWestern' Europe and Turkey. ${ }^{103}$ Furthermore, they overlook the necessity to differentiate between EU-ization (as an elite-centred formal legal process) and Europeanisation (a deeper and societal transformative cognitive process). ${ }^{104}$

${ }^{103}$ C. Rumford, Cosmopolitan Spaces: Europe, Globalization, Theory, New York, Routledge, 2008.

${ }^{104}$ A. Kaliber, "Reassessing Europeanisation as a Quest for a New Paradigm of Modernity: The Arduous Case of Turkey" Paper presented at the annual meeting of the IS A's 49th Annual Convention, Bridging Multiple Divides, San Francisco, 26 March 2008, < http://mmw.allacademic.com/meta/p254652_index.html>. 
Turkey-EU Relations: The Limitations of Europeanisation Studies

It is thereby argued that the limitations of the extant literature on Turkey-EU relations predominantly centred upon the notion of 'Europeanisation' results from the ontological and methodological problems inherent in the Europeanisation studies. In this context, there is a need to shift from Europeanisation studies and include the global dimension into the analyses of Turkey-EU relations. 